\title{
A review on the potential of empty fruit bunch (EFB) compost as growing medium for oil palm seedling production
}

\author{
Zakri, N.A. and *Adam, S. \\ Fakulti Perladangan dan Agroteknologi, Universiti Teknologi MARA, Kampus Jasin,77300, Melaka, \\ Malaysia
}

\begin{abstract}
Article history:
Received: 18 April 2021

Received in revised form: 15 June 2021

Accepted: 5 November 2021

Available Online: 26

November 2021
\end{abstract}

\section{Keywords:}

EFB compost,

Growing medium,

Oil palm seedling,

Oil palm waste

DOI:

https://doi.org/10.26656/fr.2017.5(S4).003

\begin{abstract}
The oil palm industry is among the important sectors in Malaysia. The productions of palm oil keep increasing year by year due to high demand from other countries, generating an abundance of wastes from the field and the mill. These wastes may significantly affect the environment. Composting is one of the methods to reduce the volume of waste. The compost material is widely used especially in agriculture activities due to its properties which have been enhanced during the composting process. Empty fruit bunch (EFB) compost mostly returns to the soil as mulch to conserve soil moisture and acts as organic fertilizer since it contains high nutrients needed by the plant. Currently, the depletion of fertile soil leads to less availability of growing medium, especially in the nursery. The properties of the growing medium are important to ensure better root development of seedlings and subsequently affect the overall plant growth. Therefore, numerous studies have been conducted to identify the suitable growing medium as a substitute for topsoil which is currently limited to raising seedlings in the nursery. This review examines the current methods of composting EFB and provides summarized research information on the effect of EFB compost on oil palm seedling growth. The oil palm wastes that are properly managed could produce value-added by-products and promotes sustainable agriculture practices.
\end{abstract}

\section{Introduction}

The effects of tropical climate and optimum soil conditions in Malaysia lead to the high production of oil palms in this country. In Malaysia, the total area of oil palm is approximately 5.9 million hectares and the production of crude palm oil (CPO) and palm kernel oil (PKO) in 2019 were 19.86 million tonnes and 2.32 tonnes, respectively (Parveez et al., 2020). The substantial of this industry leads to the great formation of oil palm biomass particularly empty fruit bunch (EFB) and palm oil mill effluent (POME). According to Hau et al. (2020), EFB has generated about 19 million tonnes annually. A tonne of FFB produces about $23 \%$ of EFB (Baharuddin et al., 2010) and every tonne of FFB processed produces approximately 0.6 to $0.87 \mathrm{~m}^{3}$ liquid wastes or 2.4 to 3.7 tonnes of liquid wastes per one tonne of palm oil produced with biological oxygen demand (BOD) of $20,000-25,000 \mathrm{mg} / \mathrm{L}$, chemical oxygen demand (COD) of 40,000-50,000 $\mathrm{mg} / \mathrm{L}$ and $\mathrm{pH} 3.8-4.5$ (Trisakti et al., 2015). Nevertheless, these wastes contain a substantial amount of macro- and micronutrients which are essential elements for plant growth.
Previously, most of the EFB that were produced from palm oil mills were used for boiler fuel, incineration and returned to the plantation as mulching. However, the high moisture content of EFB made it less suitable for boiler fuel, and the transformation of EFB through burning to produce fertilizers is prohibited by the Department of Environment (DOE). The burning of EFB is prohibited because it affects the environment negatively by polluting the air (Embrandiri et al., 2013). Besides, the application of mulching using EFB creates issues of soil toxicity and eutrophication (Lyana et al., 2019). Although POME is treated conventionally through an open pond, it causes a significant impact on the environment due to the enormous release of greenhouse gases (Abdullah et al., 2013). To reduce the issues of these wastes the composting is the best option.

The composting product derived from palm oil processing is widely used in the agriculture industry. Most EFB composts are used as mulches and biofertilizers. However, there are several studies conducted to identify the suitability of EFB compost as a growing medium especially for oil palm seedlings since 
the current growth media is limited. Topsoil is conventionally used as a growing medium due to its physicochemical properties that provide a conducive environment for root development. However, topsoil is currently limited due to Malaysian soil being acidic and requiring a lot of fertilizer to support plant growth (Salisu et al., 2016). The high rainfall environments lead to soil acidification where the basic cations $\mathrm{Ca}, \mathrm{Mg}, \mathrm{K}$, $\mathrm{Na}$ has leached away and resulted in the accumulation of iron and aluminium oxides and this condition lead to unfertile soil which requires more fertilizer application to increase crop production. Furthermore, the use of soil could cause incidence associated with soil-borne diseases (Salisu et al., 2016). Fungi is the most common soilborne pathogens that cause roots rot which disrupts the uptake and flow of water and nutrients through the plant. Some common root rot fungi include Cylindrocladium, Pythium, Phytophthora, and Rhizoctonia. Therefore, there is a need for an alternative growing medium to sustain the production of oil palms.

\section{Composting and enrichment of EFB compost properties}

The direct use of agricultural wastes is not suitable for land and agricultural productions because the structures of these wastes are unknown and they contain contaminants such as pathogens, weed seeds, heavy metals, and unpleasant odours (Vakili et al., 2015). Thus, composting is a feasible method to ensure the wastes are safe. Composting is a process of biomass conversion into better quality products that can be used safely. Furthermore, it offers extremely useful, manageable and environmentally friendly products. The compost materials help to enhance the properties of soil physically, chemically and biologically. The application of compost promotes microbial activities in the soil which resulted in to increase pore space of the soil. The chemical properties are enhanced through the increase of the cation exchange capacity (CEC) that influences the ability of soil to hold onto essential nutrients for plant growth. Currently, the wastes, particularly EFB and POME, that are discharged from palm oil mills in Malaysia are converted into compost. Moreover, composting of EFB can reduce the total volume of EFB up to $50-75 \%$ from the palm oil mill (Hoe et al., 2016). Thus, composting can manage the waste produced from the mill and could generate income from the commercialization of the compost produced from the agricultural sector (Then et al., 2016).

Composting EFB requires a long period due to its recalcitrant structure that is composed of lignin, cellulose and hemicelluloses, as well as other minor elements. Generally, it takes 60-90 days to achieve the maturity stage. However, this process could be intensified with the inoculation of exhibit cellulolytic and hemicellulolytic microbes that can be found from POME anaerobic sludge. There are 27 strains of indigenous microbes available to complete the composting process in 40 days (Huzairi et al., 2013). Also, the final properties of this compost material show low macronutrients and the enhancement of the compost is improved through the addition of artificial $\mathrm{N}, \mathrm{P}$ and $\mathrm{K}$ elements (Hau et al., 2020). The addition of these macronutrients will enhance the chemical properties of EFB compost and thus promote the growth of oil palm seedlings. However, the inoculations of microbes onto EFB compost only benefit the plant in short term and cause an unfavourable soil environment that may affect microbial activities.

Therefore, many studies have been carried out to enhance the final properties of EFB compost and afterwards increase the value of oil palm wastes. According to Adam et al. (2016), the addition of oil palm decanter cake (OPDC) together with EFB and POME (1:3:0.2) increase the contents of $\mathrm{N}, \mathrm{P}$ and $\mathrm{K}$ ( $\mathrm{N} 1.57 \%$, $\mathrm{P} 0.21 \%, \mathrm{~K} 0.65 \%)$. The OPDC contains a high amount of $\mathrm{N}$ which helps to speed up the composting process within 10 weeks at the lowest $\mathrm{CN}$ ratio (23.4) compared to compost material without having the OPDC. A similar finding also has been assessed by Yahya et al. (2010) on the mixtures of decanter cake slurry from palm oil mill + EFB +POME which found increased contents of nitrogen $(+46.4 \%)$, phosphorus $(+17.9 \%)$, potassium $(+17.7 \%)$ and calcium $(+23.1 \%)$. The increased nutrient content of EFB compost particularly macronutrients encourages a favourable environment for oil palm seedling growth. Meanwhile, the addition of cow dung into EFB (2:1) revealed better compost quality with increased element contents of phosphorus $(+390.54 \%)$; calcium (+373.17\%); magnesium $(+370.93 \%)$ and potassium $(+153.66 \%)($ Lim et al., 2015).

The mixing of EFB with livestock manures also can enhance the microbiological and biochemical variations during the composting. Thambirajah et al. (1995) carried out a study on the composting EFB with the addition of goat dung, cow dung, and chicken manure. The study found the mesophilic and the thermophilic bacteria were active, whereas fungal activity was decreased within the peak heating period which could minimize the incidence of diseases derived from the compost-based planting medium. Moreover, the inoculation of effective microbes (EM) into the compost materials also has been studied where the EM acts as an enhancer of the compost material. The inoculation of EM has slightly improved the content of minerals such as $\mathrm{Mg}, \mathrm{K}, \mathrm{Ca}$, and $\mathrm{B}$, as well as a key metabolite, 5-aminolevulinic acid for plant 
growth at the maturity stage of compost (Lim et al., 2015) which make the compost suitable for oil palm seedling production.

Despite composting the EFB by mixing it with other organic matters, there is a study conducted by Trisakti et al. (2017) in which the EFB was mixed with activated liquid organic fertilizer (ALOF). This material increases the nutrient value of the compost and acts as a microbial source that can enhance the composting process. ALOF can be obtained from a methanogenic anaerobic digester that produces treated biogas effluent that keeps the moisture of the compost. The final compost treated with ALOF shows good characteristics of compost where it can be used as liming material $(\mathrm{pH} 9.0)$ and acts as biofertilizer (CN ratio $12.15 \%, \mathrm{P} 0.58 \%$, and $\mathrm{K} 0.95 \%$ ). The good $\mathrm{pH}$ of compost material promotes root growth and increased nutrient uptake.

Recently, another method for composting EFB that was being studied was vermicomposting. Vermicomposting is a conversion process of organic waste through interactions with earthworms and microorganisms which can reduce the composting period (Singh et al., 2020). Vermicomposting not only accelerates the composting process but can also increase the CEC through the formation of fine fragmentation as compared to the conventional method which permits more efficient nutrient uptake by the plant and promotes better aeration. The most commonly found essential elements in vermicompost are $\mathrm{N}, \mathrm{P}, \mathrm{K}$ and $\mathrm{Mg}$. Besides that, the final product (vermicast) has the potential to hold nutrients for a longer period than the conventional compost (Hau et al., 2020). Thus, enhancement of EFB compost properties through vermicompost show the final properties of EFB compost provide an optimum planting medium, especially for oil palm seedling. A study on vermicompost produced from the mixture of $\mathrm{EFB}$ + POME with fishmeal (FM) and bonemeal (BM) showed increasing nutritional value. The $\mathrm{N}(+18$ to $62 \%)$, the $\mathrm{P}(+125$ to $906 \%)$ and the K (+262 to $294 \%)$ contents were drastically increased. The maturity can be achieved in about $40-52$ days with a $\mathrm{CN}$ ratio of less than 20 (Hau et al., 2020).

\section{The effect of EFB compost as a growth medium}

The growing medium is crucially important to produce high-quality seedlings. Conventional topsoil is used as a growing medium to raise oil palm seedlings because the topsoil contains high nutrients with good physical properties that can support the growth of the seedling. However, this practice needs to reassess since the topsoil is currently a limited source for the future of the oil palm industry. To supply oil palm seedling for 136 palms per hectare, it requires about 0.143 hectares of topsoil at the depth of $15 \mathrm{~cm}$ for the pre-nursery and another 1.60 hectares of topsoil at the same depth for the main nursery. Therefore, the total area of 1742 ha at the depth of $15 \mathrm{~cm}$ topsoil needs to be supplied for nursery operations (Suryanto and Wachjar, 2015). High production of palm oil in this country causes depletion of topsoil and degradation of the area from which it is collected. Moreover, the use of topsoil is heavy to handle especially during the transplanting process from nursery to field (Shahkhirat et al., 2016). Hashim et al. (1987) stated that the growth medium such as peat, dried effluent, and coir dust is suitable to be used for raising oil palm seedlings in the nursery (Shahkhirat et al., 2016). The use of organic substrate for plant growth media is the best option since it is readily available, less expensive, and conserves the environment. Many positive results have been recorded from previous studies on the effects of organic material in raising oil palm seedlings.

\subsection{Oil palm seedling growth}

The enrichment of the EFB compost properties through the addition of several organic substances and inoculation of microbes during composting lead to the utilization of EFB compost as soil substitutes for raising oil palm seedlings in the nursery. Suryanto and Wachjar (2015) discovered the use of compost and vermicompost which can substitute topsoil for raising oil palm seedlings in double stage nurseries since the compost has a nutrient grade of $\mathrm{N}(1.32 \%), \mathrm{P}(0.49 \%)$ and $\mathrm{K}(0.06 \%)$, while vermicompost has $\mathrm{N}(1.05 \%), \mathrm{P}(0.58 \%)$ and $\mathrm{K}$ $(0.03 \%)$. The application of compost showed better morphological and physiological growth although it is not significantly different with vermicompost treatment. Studies by Rovica et al. (2018), shows the application of EFB compost mixture as a soil amendment for oil palm seedling significantly improved physicochemical properties of the polybag medium and root development of the seedling. The high root volume of the seedling will increase the survival rate after field planting because the high volume root system results in greater capability for absorption and transportation of water, thus improving the plant's ability to handle environmental stress (Jacobs et al., 2005). In addition, the high percentage of oil palm compost as a growing medium could reduce the heavy structure and compaction of the soil. Soil compaction could have caused root restriction that may cause poor plant vegetative growth. As assessed by Seman et al. (2018), a compost-based planting medium has the potential to influence seedling as an alternative growth medium compared to the soils used in oil palm nurseries. 


\subsection{Plant nutrient uptake}

The addition of EFB compost increased nutrient availability and retention in the growing medium. The surface of organic matter-like compost is rich in negative functionalities such as phenolic, carboxylic, carbonyl, and alcohol which serve as exchange sites that ultimately increased the CEC of growth media and subsequently promote efficient nutrient usage (Palanivell et al., 2013). As assessed by Rosenani et al. (2016) the nutrient uptakes (N, P, K, Mg, Ca, Fe, $\mathrm{Zn}$ and $\mathrm{Cu}$ ) are high for oil palm seedlings grown in $60-100 \%$ of compost media. Macronutrients (particularly N, P and K) played a vital role, especially in the growth of young oil palm. According to Rovica et al. (2018), oil palm shoot biomass was positively correlated with $\mathrm{N}$ and $\mathrm{K}$ uptake. The $\mathrm{N}$ and $\mathrm{K}$ are the essential nutrients for the improvement of vegetative dry matter production and leaf area index of young oil palm (Corley and Mok, 1972).

Furthermore, the mixture of EFB compost with topsoil showed positive effects of improving physical properties, exchange and buffering capacities, and becoming nutrient sources for plant uptake. These properties lead to an increase in the seedling dry matter weight up to $71 \%$ at the main nursery stage as the composted EFB and POME were applied at the rate of $150 \mathrm{~g}$ per polybag in a study by Aisueni and Omoti (2001) as cited by (Rosenani et al., 2016). However, the rate of compost needs to properly be identified because according to Zhang et al. (2013), the application of compost for more than $70 \%$ causes a reduction in plant growth and root morphology. This could be attributed to the presence of phytotoxic substances and negative changes in the chemical and the physical properties of growth media (Zhang et al., 2013; Rosenani et al., 2016). On the other hand, according to Rosenani et al. (2016), oil palm seedlings in the pre-nursery stage showed the best growth performance with the application of $72 \%$ of oil palm compost mixed with topsoil.

According to Hastuti and Rohmiyati (2020), the application of EFB compost that was inoculated with phosphate solubilizing bacteria (PSB) on latosols soil has increased the height of oil palm seedlings in the prenursery. The addition of organic matter to the soil will produce chelation of polyvalent cations by organic acids and other decay products that caused increased $\mathrm{P}$ availability in soil. The inoculation of PSB also can produce plant growth regulators such as indole acetic acid (IAA) and gibberellin (GA) that could promote oil palm seedling growth (Hastuti and Rohmiyati, 2020). In addition, the high availability of $\mathrm{P}$ through the inoculation of PSB on EFB compost could reduce the cost of fertilizer for nursery operations. It was supported by Siregar et al. (2002), the combination of EFB compost with topsoil can substitute the conventional manuring program in the main nursery.

\section{Conclusion}

The various method of composting EFB shows the EFB compost can be used as a planting medium for oil palm seedling. The enhancement of its physicochemical properties especially the nutrients content indicate that these materials can fulfil the requirements of a suitable planting medium for oil palm seedling productions. EFB compost also could be used as a biofertilizer which would reduce the manuring cost in oil palm nurseries. Furthermore, the use of EFB compost provides a lightweight planting medium which is important for handling and transportation. The lightweight planting medium would reduce the burden for workers during field panting operation and increase palm distribution time during planting or replanting exercise. Despite this, oil palm waste management is essential to minimize environmental impact and to ensure a sustainable palm oil industry. The utilization of EFB in large volumes could manage these major palm oil mill wastes and can also reduce the cost and subsequently increase the income. Research and innovations together with technology are required to ensure the final properties of EFB compost can be used for plant growth media to ensure the source of growing media for oil palm seedlings are available and accessible for sustaining the palm oil industry in Malaysia.

\section{References}

Abdullah, N., Sulaiman, F. and Aliasak, Z. (2013). A case study of pyrolysis of oil palm wastes in Malaysia. AIP Conference Proceedings, 1528(1), 331-336. https://doi.org/10.1063/1.4803619

Adam, S., Syd Ahmad, S.S.N., Hamzah, N.M. and Darus, N.A. (2016). Composting of Empty Fruit Bunch Treated with Palm Oil Mill Effluent and Decanter Cake. In Yacob, N., Mohamed, M., Megat Hanafiah, M. (Eds.) Regional Conference on Science, Technology and Social Sciences (RCSTSS 2014), p. 437-445. Singapore: Springer. https:// doi.org/10.1007/978-981-10-0534-3_43

Aisueni, N.O. and Omoti, U. (2001). The role of compost in sustainable oil palm production. Cuttingedge technologies for sustainable oil palm production: Proceedings of the 2001 PIPOC International Palm Oil Congress, Agriculture Conference, 20 - 22 AUgust 2001, p. 536-541. Kuala Lumpur, Malaysia: Malaysian Palm OIl Board (MPOB).

Baharuddin, A.S., Hock, L.S., Yusof, M.Z.M., Rahman, 
N.A.A., Shah, U.K.M., Hassan, M.A., Wakisaka, M., Sakai, K. and Shirai, Y. (2010). Effects of palm oil mill effluent (POME) anaerobic sludge from $500 \mathrm{~m}^{3}$ of closed anaerobic methane digested tank on pressed-shredded empty fruit bunch (EFB) composting process. African Journal of Biotechnology, 9(16), 2427-2436.

Corley, R.H.V. and Mok, C.K. (1972). Effects of nitrogen, phosphorus, potassium and magnesium on growth of the oil palm. Experimental Agriculture, 8 (4), 347-353. https://doi.org/10.1017/ S0014479700005470

Embrandiri, A., Ibrahim, M.H. and Singh, R.P. (2013). Palm Oil Mill Wastes Utilization; Sustainability in the Malaysian Context. International Journal of Scientific and Research Publications, 3(3), 1-7.

Hashim, M.T., Yeow K.H. and Poon, Y C. (1987). Recent development in nursery practice - potting media. Proceedings of the 1987 International Palm Oil/ Plant Oil Conferences. Progress and Prospects. Conference I-Agriculture, p. 369-371. Kuala Lumpur, Malaysia.

Hastuti, P.B. and Rohmiyati, S.M. (2020). Application of Empty Fruit Bunches Compost and Types of $\mathrm{P}$ Fertilizer on the Growth and Phosphorus Uptake in Oil Palm Seedlings. Agrotechnology Research Journal, 4(2), 59-64. https://doi.org/10.20961/ agrotechresj.v4i2.40784

Hau, L.J., Shamsuddin, R., May, A.K.A., Saenong, A., Lazim, A.M., Narasimha, M. and Low, A. (2020). Mixed Composting of Palm Oil Empty Fruit Bunch (EFB) and Palm Oil Mill Effluent (POME) with Various Organics: An Analysis on Final Macronutrient Content and Physical Properties. Waste and Biomass Valorization, 11(10), 55395548. https://doi.org/10.1007/s12649-020-00993-8

Then, K.H., Sarmidi, M.R., Syed Alwee, S.S.R. and Zakaria, Z.A. (2016). Recycling of oil palm empty fruit bunch as potential carrier for biofertilizer formulation. Jurnal Teknologi, 78, 165-170. https:// doi.org/10.11113/jt.v78.7375

Huzairi, M., Zainudin, M., Ali, M., Tokura, M. and Shirai, Y. (2013). Bioresource Technology Indigenous cellulolytic and hemicellulolytic bacteria enhanced rapid co-composting of lignocellulose oil palm empty fruit bunch with palm oil mill effluent anaerobic sludge. Bioresource Technology, 147, 632 -635. https://doi.org/10.1016/j.biortech.2013.08.061

Jacobs, D.F., Salifu, K.F. and Seifert, J.R. (2005). Relative contribution of initial root and shoot morphology in predicting field performance of hardwood seedlings. New Forests, 30, 235-251. https://doi.org/10.1007/s1 1056-005-5419-y
Lim, L.Y., Chua, L.S. and Lee, C.T. (2015). Effects of microbial additive on the physiochemical and biological properties of oil palm empty fruit bunches compost. Journal of Engineering Science and Technology, 10(Spec. issue5), 10-18.

Lyana, N., Mohamad, B., Phoon, C.L., Yoon, L.W. and Teck, W. (2019). The Effect of Activated Organic Sludge on the Process and Quality of Composting Palm Oil Empty Fruit Bunches. AIP Conference Proceedings, 2137(1), 020011.

Palanivell, P., Susilawati, K., Ahmed, O.H. and Muhamad, A.M.N. (2013). Effects of crude humin and compost produced from selected waste on Zea mays growth, nutrient uptake and nutrient use efficiency. African Journal of Biotechnology 12(13), 1500-1507. https://doi.org/10.1155/2013/276235

Parveez, G.K.A, Hishamuddin, E., Loh, S.K., OngAbdullah, M., Salleh, K.M., Zanal Bidin, M.N.I, Sundram, S., Hasan, Z.A.A. and Idris, Z. (2020). Oil Palm Economic Performance in Malaysia and R\&D Progress in 2019. Journal of Oil Palm Research, 32, 159-190.

Rovica, R., Rosenani, A.B., Che Fauziah, I., Siti Hajar, A. and Tsong, L.C. (2018). Biochar-compost mixture as amendment for improvement of polybag-growing media and oil palm seedlings at main nursery stage. International Journal of Recycling of Organic Waste in Agriculture 7, 11-23. https://doi.org/10.1007/ s40093-017-0185-3

Rosenani, A.B., Rovica, R., Cheah, P.M. and Lim, C.T. (2016). Growth Performance and Nutrient Uptake of Oil Palm Seedling in Prenursery Stage as Influenced by Oil Palm Waste Compost in Growing Media. International Journal of Agronomy, 2016, 6930735. https://doi.org/10.1155/2016/6930735

Salisu, M.A., Daud, W.N., Halim, R.A. and Sulaiman, Z. (2016). Effect of soilless media on growth and some physiological traits of rubber (Hevea brasiliensis) seedlings. International Journal of Agriculture, Forestry and Plantation, 3, 95-100.

Seman, I.F., Zulkefley, S., Adekunle, S.M. and Samad, M.Y.A. (2018). Effect of Different Media Combination on Growth and Biomass Production of Oil Palm (Elaeis guineensis) Seedlings. International Journal of Environment, Agriculture and Biotechnology, 3(1), 140-146. https:// doi.org/10.22161/ijeab/3.1.18

Norizan, M.S., Mohamad, M.K., Kamaruzaman, A.A.B. and Arifin, I. (2016). Evaluation of organic matter as potting media. The Planter, 91(1067), 101-111.

Singh, R., Srivastava, P., Verma, P., Singh, P., Bhadouria, R., Singh, V.K., Singh, H. and 
Raghubanshi, A.S. (2020). Chapter 21. Exploring soil responses to various organic amendments under dry tropical agroecosystems. In Prasad, M.N.V. and Pietrzykowski, M. (Eds.) Climate Change and Soil Interactions, p. 583-612. USA: Elsevier Ltd. https:// doi.org/10.1016/B978-0-12-818032-7.00021-7

Siregar, F.A., Salates, S., Caliman, J.P. and Liwang, Z. (2002). Empty fruit bunch compost: Processing and utilization. Proceedings of International of Oil Palm Conf Nusa Dua, p. 225-234. Bali, Indonesia.

Suryanto, T. and Wachjar, A. (2015). The Growth of Oil Palm ( Elaeis guineensis Jacq .) Seedlings at Various Media and Containers in Double Stage Nursery. Asian Journal of Applied Sciences, 3(5), 664-671.

Thambirajah, J.J., Zulkifli, M.D. and Hashim, M.A. (1995) Microbiological and biochemical changes during the composting of oil palm empty fruit bunches; effect of nitrogen supplementation on the substrate. Bioresource Technology, 52(2) 133-144. https://doi.org/10.1016/0960-8524(95)00008-3

Trisakti, B., Manalu, V., Taslim, I. and Turmuzi, M. (2015). Acidogenesis of Palm Oil Mill Effluent to Produce Biogas: Effect of Hydraulic Retention Time and pH. Procedia - Social and Behavioral Sciences, 195, 2466-2474. https://doi.org/10.1016/ j.sbspro.2015.06.293

Trisakti, B., Lubis, J., Husaini, T. and Irvan. (2017). Effect of Turning Frequency on Composting of Empty Fruit Bunches Mixed with Activated Liquid Organic Fertilizer. IOP Conference Series: Materials Science and Engineering, 180, 012150. https:// doi.org/10.1088/1757-899X/180/1/012150

Vakili, M., Rafatullah, M., Ibrahim, M.H., Salamatinia, B., Gholami, Z. and Zwain, H.M. (2015). A review on composting of oil palm biomass. In Environment, Development and Sustainability, 17(4), 691-709. https://doi.org/10.1007/s10668-014-9581-2

Yahya, A., Sye, C.P., Ishola, T.A. and Suryanto, H. (2010). Effect of adding palm oil mill decanter cake slurry with regular turning operation on the composting process and quality of compost from oil palm empty fruit bunches. Bioresource Technology, 101(22), 8736-8741. https://doi.org/10.1016/ j.biortech.2010.05.073

Zhang, L., Sun, X., Tian, Y. and Gong, X. (2013). Composted green waste as a substitute for peat in growth media: effects on growth and nutrition of Calathea insignis. PloS One, 8(10), e78121. https:// doi.org/10.1371/journal.pone.0078121 